AL IBTIDA: JURNAL PENDIDIKAN GURU MI (2017) VOL. 4(2): 217-226

DOI: http://dx.doi.org/10.24235/al.ibtida.snj.v4i2.1677

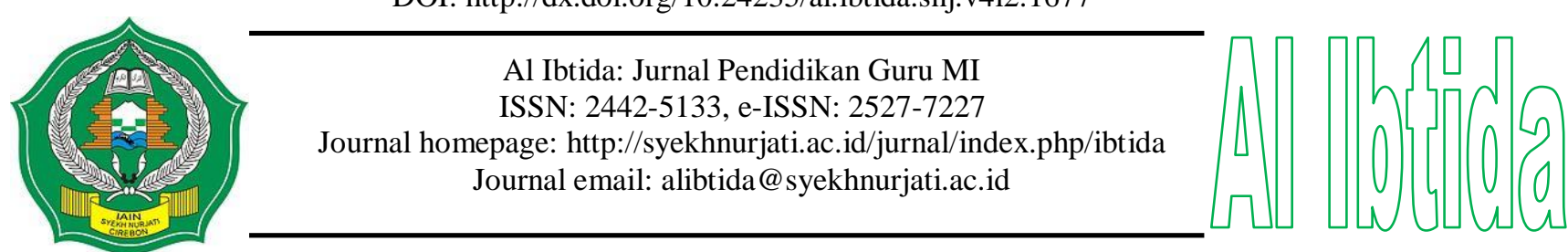

\title{
Implementasi Pendidikan Agama Islam Pada Keluarga \\ (Studi Kasus Pengembangan Karakter Kepribadian Anak di MI Al-Wasliyah Sumber Kabupaten Cirebon)
}

\author{
Dwi Anita Alfiani* \\ *Jurusan Pendidikan Guru Madrasah Ibtidaiyah, Fakultas Ilmu Tarbiyah dan Keguruan, \\ IAIN Syekh Nurjati Cirebon \\ Email: deamers77@gmail.com \\ Maman Rusman** \\ **Jurusan Manajemen Pendidikan Islam, Fakultas Ilmu Tarbiyah dan Keguruan, \\ IAIN Syekh Nurjati Cirebon \\ Email: riqyfana.alma@gmail.com
}

Received 28 July 2017; Received in revised form: 09 October 2017; Accepted 14 October 2017 Publish Online: 27 October 2017

\begin{abstract}
Abstrak
Pendidikan dalam keluarga merupakan pendidikan yang pertama dan utama bagi anak. Pendidikan yang diberikan secara sadar oleh orang tua kepada anak-anaknya ini ditujukan agar anak-anak memiliki sikap dan tingkah laku yang baik sesuai dengan ajaran Islam. Keberagaman seseorang terwujud di dalam bentuk tingkah laku/akhlak dan perbuatannya sehari-hari yang akhirnya menjadi sifat atau kepribadian yang dapat melahirkan perbuatan baik dan buruk. Penelitian ini bertujuan untuk memperoleh data tentang sejauhmana implementasi Pendidikan Agama Islam dalam lingkungan keluarga siswa, mengetahui data tentang akhlak/perilaku keseharian siswa dan untuk memperoleh data tentang impliksi pendidikan agama Islam dalam keluarga terhadap akhlak anak di MI AlWashliyah Sumber Kab. Cirebon. Teknik pengumpulan data dalam penelitian ini adalah dengan menyebarkan angket yang berisi sejumlah pernyataan tentang implementasi pendidikan agama Islam dalam keluarga dan karakter anak MI Al-Washliyah Sumber Kab. Cirebon. Jawaban angket tersebut dihitung dengan rumus prosentase kemudian diolah dan dianalisis secara deskriptif. Selain itu, peneliti memperoleh data penunjang lainnya melalui dokumentasi, wawancara kepada wali kelas dan orang tua siswa. Hasil penelitian menunjukkan bahwa terdapat pengaruh positif dan signifikan antara implementasi pendidikan agama Islam dalam keluarga terhadap pembentukan karakter anak MI Al-Washliyah Sumber Kab. Cirebon. Hal ini terlihat dari pelaksanaan sholat lima waktu anak sudah membiasakan tepat diawal waktu, kesadaran membaca al-quran dan membantu orang tua dalam mengerjakan tugas keseharian di Rumah.
\end{abstract}

Kata kunci: pendidikan agama Islam, keluarga, karakter 


\begin{abstract}
Education in the family is the first and primary education for children. Education provided consciously by parent to their children, the goal is that children have a good attitude and behavior in accordance with the teachings of Islam. The diversity of a person manifests in the form of behavior / morals and daily deeds that eventually become the nature or personality that can give birth to good and bad deeds. This study aims to obtain data on the extent to which the implementation of Islamic Religious Education in the family environment of students, know the data about morals / student's daily behavior and to obtain data about the implication of Islamic religious education in the family against morality of children in MI Al-Washliyah Sumber Kab. Cirebon. Data collection technique in this study is distributing a questionnaire containing a number of statements about the implementation of Islamic religious education in the family and about the character of MI Al-Washliyah Sumbre Kab. Cirebon. The answer of questionnaire is calculated by the percentage formula then processed and explained descriptively. In addition, researcher get other supporting data through documentation, interviews to teacher and parents of students. The result of study showed that there is a positive and significant influence between the implementation of Islamic religious education in the family against the formation of children character MI Al-Washliyah Sumber, Cirebon regency, like the five-time prayers the children are getting used to in the beginning of time, awareness of reading the Qur'an and helping parents in doing daily chores at Home.
\end{abstract}

Keywords: islamic education, family, character.

\title{
PENDAHULUAN
}

Keluarga merupakan unit sosial terkecil yang utama dan pertama bagi seorang anak. Sebelum ia berkenalan dengan dunia sekitarnya, ia akan berkenalan telebih dahulu dengan situasi keluarga. Pengalaman pergaulan dalam keluarga akan memberikan pengaruh yang sangat besar bagi perkembangan anak untuk masa yang akan datang. Keluargalah yang akan memberikan warna kehidupan seorang anak, baik perilaku, budi pekerti maupun adat kebiasaan sehari-hari. Keluarga juga merupakan tempat dimana seorang anak mendapat tempaan pertama kali yang kemudian menentukan baik buruk kehidupan setelahnya di masyarakat. Sehingga tidak salah lagi kalau keluarga adalah elemen penting dalam menentukan baik-buruknya masyarakat (Al-Abrasy, 1993: 133). Fakta di lapangan menunjukkan bahwa masih banyak anak-anak usia MI/SD yang masih belum mampu menyadari tentang kewajibannya, misalnya melaksanakan shalat lima watu sebagai kewajiban seorang muslim atau anak-anak belum mempunyai kesadaran untuk membantu orang tua dalam melaksanakan tugas keseharian di rumah, bahkan masih banyak terjadi intimidasi antar anak-anak di sekolahnya.

Maka, untuk mewujudkan apa yang diharapkan keluarga dalam membentuk karakter anak perlu adanya upaya pendidikan. Pendidikan adalah upaya sadar dan terencana dalam proses pembimbingan dan pembelajaran bagi individu agar tumbuh berkembang menjadi manusia yang mandiri, bertanggungjawab, kreatif, berilmu, sehat, dan berakhlak (berkarakter) mulia (UU No. 20 tahun 2003 pasal 3). Sistem Pendidikan Nasional (Sisdiknas) menegaskan bahwa pendidikan 
nasional berfungsi untuk mengembangkan kemampuan dan membentuk watak serta peradaban bangsa yang bermartabat dalam rangka mencerdaskan kehidupan bangsa, bertujuan untuk berkembangnya potensi peserta didik agar menjadi manusia yang beriman dan bertaqwa kepada Tuhan YangMaha Esa, berakhlak mulia, sehat, berilmu, cakap, kreatif, mandiri, dan menjadi warga Negara yang demokratis serta bertanggungjawab (UU No.20 tahun 2003 pasal 3).

Berdasarkan hukum yuridis tersebut, pendidikan nasional mengemban misi untuk membangun manusia sempurna (insan kamil). Untuk membangun bangsa dengan jati diri yang utuh, dibutuhkan sistem pendidikan yang memiliki materi yang berbasis nilai karakter, serta ditopang oleh pengelolaan dan pelaksanaan yang baik. Dengan demikian, pendidikan nasional harus bermutu dan berkarakter. Dalam mata pelajaran tentunya terdapat standar kompetensi (SK), kompetensi dasar (KD) maupun indikator dalam pembelajaran dan nilai-nilai karakter yang dikembangkan sehingga mampu untuk mencapai tujuan dan mewujudkan nilai-nilai karakter yang dikembangkan dari mata pelajaran tersebut. Dalam hal ini seorang guru dituntut untuk dapat meningkatkan aspek kognitif dan psikomotorik pada siswa sekaligus mampu meningkatkan dan membentuk karakter siswa secara kuat sesuai dengan apa yang diharapkan.

Berdasarkan pemaparan berbagai teori di atas, seyogyannya pendidikan agama Islam pada keluarga akan sangat berpengaruh terhadap pengembangan karakter kepribadian anak yang baik. Tetapi dalam kenyataannya banyak terlihat fenomena bahwa perilaku, gaya bicara, sopan santun sudah tidak dihiraukan dalam kehidupan sehari-hari, apa lagi sebagai seorang muslim yang harus menjalankan kewajiban sholat lima waktu mereka masih enggan, mereka masih harus selalu diingatkan. Walaupun kalau dilihat secara kasat mata, pendidikan agama Islam keluarga bahkan tempat menimba ilmu anak tersebut banyak muatan pendidikan agamanya, dengan harapan mampu membawa perubahan pada anak dalam perkembangan karakter kepribadian.

Menurut Darajat (2006), Pendidikan agama Islam adalah suatu usaha untuk membina dan mengasuh peserta didik agar senantiasa dapat memahami ajaran Islam secara menyeluruh. Lalu menghayati tujuan, yang pada akhirnya dapat mengamalkan serta menjadikan Islam sebagai pandangan hidup. Sedangkan menurut Ahmad Tafsir mengemukakan bahwa pendidikan agama Islam adalah bimbingan yang diberikan seseorang kepada seseorang agar ia berkembang secara maksimal sesuai dengan ajaran Islam. Pendidikan agama mempunyai kedudukan yang tinggi dan paling utama, karena pendidikan agama menjamin dapat memperbaiki akhlak anak didik dan mengangkat mereka ke derajat yang tinggi, serta berbahagia dalam hidup dan kehidupannya. Pendidikan agama juga dapat membersihkan hati dan mensucikan jiwa, serta mencetak mereka agar berkelakuan yang baik dan mulia.

Melihat fenomena yang berkembang tersebut, merupakan gambaran minimnya perhatian orang tua/keluarga terhadap pendidikan, baik pendidikan agama Islam maupun kurangnya 
kesadaran orang tua terhadap perkembangan karakter kepribadian anak. Kurang memahaminya orang tua akan pendidikan Islam mengakibatkan rendahnya motivasi belajar yang diberikan orang tua pada pendidikan agama Islam. Mengingat banyaknya permasalahan dan fenomena yang peneliti temukan, maka penelitian ini bertujuan untuk mengetahui implementasi Pendidikan Agama Islam pada anak dalam keluarga, bagaimana upaya keluarga dalam menghadapi hambatan dalam mengimplementasikan Pendidikan Agama Islam dalam keluarga, serta implikasi implementasi Pendidikan Agama Islam dalam keluarga terhadap perkembangan kepribadian anak.

\section{METODE PENELITIAN}

Pendekatan yang digunakan dalam penelitian ini adalah pendekatan kualitatif. Pendekatan kualitatif adalah suatu paradigma penelitian untuk mendiskripsikan peristiwa, perilaku orang, atau suatu keadaan pada tempat tertentu secara rinci dan mendalam dalam bentuk narasi. Penelitian dengan pendekatan kualitatif ini menggunakan paradigma positivistik yang tidak menerima hanya satu kebenaran, karena kebenaran itu kompleks, mengungkapkan gambaran yang mendalam dan holistik. Oleh karena itu penelitian dilakukan dalam situasi yang wajar (natural setting).

Penelitian kualitatif sifatnya diskriptif, karena data yang dianalisis tidak untuk menerima atau menolak hipotesis (Jika ada) melainkan hasil analisis itu berupa diskripsi dari gejala-gejala yang di amati, yang tidak selalu harus berbentuk angka-angka atau koofesien antar variable. Penelitian kualitatif pun bukan tidak mungkin ada data yang kuantitatif karena kulitatif cenderung berkembang dan banyak digunakan dalam ilmu-ilmu sosial yang berhubungan dengan prilaku sosial atau manusia. Adapun metode yang digunakan peneliti dalam penelitian ini adalah metode penelitian deskriptif, yaitu suatu metode penelitian yang berusaha untuk meyajikan data dan fakta-fakta yang sesungguhnya tentang peranan keluarga dalam pelaksanaan pendidikan agama Islam dengan menyebarkan angket (kuesioner) kepada responden di tempat diadakan penelitian.

Dalam menyusun penelitian ini, peneliti menggunakan metode deskriptif analisis yang didasarkan pada data atau informasi yang diperoleh melalui penelitian sebagai berikut:

1. Field Research yaitu mengumpulkan data-data dengan jalan meneliti langsung ke objek yang bersangkutan (turun ke lapangan)

2. Library Research yaitu mengumpulkan data-data dan fakta-fakta dengan meneliti dari beberapa buku yang berkaitan dengan permasalahan yang dibahas.

Adapun sumber data dalam penelitian ini adalah guru, siswa, dan orang tua siswa $\mathrm{MI} \mathrm{Al}$ Washliyah Sumber Kabupaten Cirebon. Sementara itu, data dikumpulkan dengan menggunakan 
angket, wawancara dan dokumentasi. Setelah data terkumpul, kemudian dianalisis secara deskriptif.

\section{HASIL DAN PEMBAHASAN}

\section{A. Implementasi Pendidikan Agama Islam pada Anak dalam Keluarga}

Hasil analisis angket implementasi pendidikan agama Islam pada keluarga dalam mengembangkan karakter kepribadian anak di MI Al-Wasliyah Sumber Kabupaten Cirebon adalah sebagai berikut:

Tabel 1. Rekapitulasi Angket Implementasi Pendidikan Agama Islam

\begin{tabular}{|c|c|c|c|c|c|c|c|c|c|c|}
\hline \multirow{2}{*}{ No } & \multicolumn{2}{|l|}{$\mathrm{TP}$} & \multicolumn{2}{|l|}{$\mathrm{P}$} & \multicolumn{2}{|l|}{$\mathrm{Kd}$} & \multicolumn{2}{|l|}{$\mathrm{Sl}$} & \multicolumn{2}{|c|}{ JUMLAH } \\
\hline & $\mathrm{F}$ & $\mathrm{P}$ & $\mathrm{F}$ & $\mathrm{P}$ & $\mathrm{F}$ & $\mathrm{P}$ & $\mathrm{F}$ & $\mathrm{P}$ & $\mathrm{F}$ & $\mathrm{P}$ \\
\hline 1 & 0 & $0 \%$ & 2 & $10 \%$ & 10 & $50 \%$ & 8 & $40 \%$ & 20 & $100 \%$ \\
\hline 2 & 1 & $5 \%$ & 5 & $25 \%$ & 8 & $40 \%$ & 6 & $30 \%$ & 20 & $100 \%$ \\
\hline 3 & 0 & $0 \%$ & 0 & $0 \%$ & 11 & $55 \%$ & 9 & $45 \%$ & 20 & $100 \%$ \\
\hline 4 & 0 & $0 \%$ & 2 & $10 \%$ & 11 & $55 \%$ & 7 & $35 \%$ & 20 & $100 \%$ \\
\hline 5 & 13 & $65 \%$ & 6 & $30 \%$ & 1 & $5 \%$ & 0 & $0 \%$ & 20 & $100 \%$ \\
\hline 6 & 0 & $0 \%$ & 3 & $15 \%$ & 13 & $65 \%$ & 4 & $20 \%$ & 20 & $100 \%$ \\
\hline 7 & 0 & $0 \%$ & 3 & $15 \%$ & 10 & $50 \%$ & 7 & $35 \%$ & 20 & $100 \%$ \\
\hline 8 & 7 & $35 \%$ & 8 & $40 \%$ & 5 & $25 \%$ & 0 & $0 \%$ & 20 & $100 \%$ \\
\hline 9 & 0 & $0 \%$ & 1 & $5 \%$ & 9 & $45 \%$ & 10 & $50 \%$ & 20 & $100 \%$ \\
\hline 10 & 4 & $20 \%$ & 13 & $65 \%$ & 3 & $15 \%$ & 0 & $0 \%$ & 20 & $100 \%$ \\
\hline 11 & 6 & $30 \%$ & 10 & $50 \%$ & 4 & $20 \%$ & 0 & $0 \%$ & 20 & $100 \%$ \\
\hline 12 & 0 & $0 \%$ & 3 & $15 \%$ & 14 & $70 \%$ & 3 & $15 \%$ & 20 & $100 \%$ \\
\hline 13 & 9 & $45 \%$ & 7 & $35 \%$ & 4 & $20 \%$ & 0 & $0 \%$ & 20 & $100 \%$ \\
\hline 14 & 0 & $0 \%$ & 0 & $0 \%$ & 7 & $35 \%$ & 13 & $65 \%$ & 20 & $100 \%$ \\
\hline 15 & 0 & $0 \%$ & 1 & $5 \%$ & 12 & $60 \%$ & 7 & $35 \%$ & 20 & $100 \%$ \\
\hline 16 & 3 & $15 \%$ & 3 & $15 \%$ & 7 & $35 \%$ & 7 & $35 \%$ & 20 & $100 \%$ \\
\hline 17 & 4 & $20 \%$ & 12 & $60 \%$ & 4 & $20 \%$ & 0 & $0 \%$ & 20 & $100 \%$ \\
\hline 18 & 6 & $30 \%$ & 12 & $60 \%$ & 2 & $10 \%$ & 0 & $0 \%$ & 20 & $100 \%$ \\
\hline 19 & 0 & $0 \%$ & 4 & $20 \%$ & 13 & $65 \%$ & 3 & $15 \%$ & 20 & $100 \%$ \\
\hline 20 & 5 & $25 \%$ & 10 & $50 \%$ & 5 & $25 \%$ & 0 & $0 \%$ & 20 & $100 \%$ \\
\hline $\begin{array}{l}\text { Rata- } \\
\text { rata }\end{array}$ & 2,9 & $15 \%$ & 5,25 & $26 \%$ & 7,65 & $38 \%$ & 4,2 & $21 \%$ & 20 & $100 \%$ \\
\hline
\end{tabular}

Berdasarkan tabel rekapitulasi angket di atas, hasil rekapitulasi angket rata-rata siswa yang menyatakan tidak pernah $15 \%$, siswa yang menyatakan pernah $26 \%$, siswa yang menyatakan kadang-kadang 38\%, dan siswa yang menyatakan selalu $21 \%$. Presentasi tersebut diperoleh dari jumlah frekuensi masing-masing alternatif jawaban ( $\mathrm{Sl}, \mathrm{Kd}, \mathrm{P}, \mathrm{TP})$ pada tiap item instrumen angket implementasi Pendidikan Agama Islam. Dengan demikian implementasi Pendidikan Agama Islam di MI Al-Wasliyah Sumber Kabupaten Cirebon direspon positif. 
Hasil analisis menunjukkan bahwa implementasi pendidikan agama Islam di keluarga kepada anak-anak memiliki kriteria yang sangat kuat. Hal ini digambarkan bahwa apabila kurang komunikasi antara orang tua dengan anak dalam hal pembiasaan sholat lima waktu misalnya, orang tua tidak pernah menanyakan dan mengingatkan maka tidak akan atau sulit untuk terjadinya implementasi pendidikan agama Islam dalam keluarga tersebut. Sejalan dengan pendapat Hurlock (2000: 204) bahwa pola asuh permisif terlihat pada orang tua yang membiarkan anak berbuat sesuka hati dengan sedikit kekangan, kontrol yang sangat longgar terhadap anak, hukuman dan hadiah tidak pernah di berikan, semua keputusan di serahkan kepada anak, orang tua bersikap masa bodoh dan pendidikan bersifat bebas.

Dalam perspektif pendidikan, terdapat tiga lembaga utama yang sangat berpengaruh dalam perkembangan kepribadian seorang anak yaitu lingkungan keluarga, lingkungan sekolah dan lingkungan masyarakat, yang selanjutnya dikenal dengan istilah Tripusat Pendidikan. Dalam $\neg$ GBHN (Tap. MPR No. IV/MPR/1978) ditegaskan bahwa pendidikan berlangsung seumur hidup dan dilaksanakan dalam lingkungan rumah tangga, sekolah dan masyarakat. Oleh karena itu, pendidikan merupakan tanggung jawab bersama antara keluarga, masyarakat dan pemerintah (Darajat, 1995).

Lembaga keluarga merupakan tempat pertama untuk anak menerima pendidikan dan pembinaan. Meskipun diakui bahwa sekolah mengkhususkan diri untuk kegiatan pendidikan, namun sekolah tidak mulai dari "ruang hampa"(NoerAly, 1999). Urgensi penerapan pendidikan agama terhadap anak dalam keluarga pendidikan agama merupakan pendidikan dasar yang harus diberikan kepada anak sejak dini ketika masih muda. Hal tersebut mengingat bahwa pribadi anak pada usia kanak-kanak masih muda untuk dibentuk dan anak didik masih banyak berada di bawah pengaruh lingkungan rumah tangga. Mengingat arti strategis lembaga keluarga tersebut, maka pendidikan agama yang merupakan pendidikan dasar itu harus dimulai dari rumah tangga oleh orang tua. Pendidikan agama dan spiritual termasuk bidangbidang pendidikan yang harus mendapat perhatian penuh oleh keluarga terhadap anakanaknya. Pendidikan agama dan spiritual ini berarti membangkitkan kekuatan dan kesediaan spiritual yang bersifat naluri yang ada pada kanak-kanak. Demikian pula, memberikan kepada anak bekal pengetahuan agama dan nilai-nilai budaya Islam yang sesuai dengan umurnya sehingga dapat menolongnya kepada pengembangan sikap agama yang betul. Inti pendidikan agama sesungguhnya adalah penanaman iman kedalam jiwa anak didik, dan untuk pelaksanaan hal itu secara maksimal hanya dapat dilaksanakan dalam rumah tangga.

Nasution (1995) menyebutkan bahwa pendidikan agama, dalam arti pendidikan dasar dan konsep Islam adalah pendidikan moral. Pendidikan budi pekerti luhur yang berdasarkan 
agama inilah yang harus dimulai oleh ibu-bapak di lingkungan rumah tangga. Disinilah harus dimulai pembinaan kebiasaan-kebiasaan yang baik dalam diri anak didik. Lingkungan rumah tanggalah yang dapat membina pendidikan ini, karena anak yang berusia muda dan kecil itu lebih banyak berada di lingkungan rumah tangga daripada di luar .Tugas lingkungan rumah dalam hal pendidikan moral itu penting sekali, bukan hanya karena usia kecil dan muda anak didik serta besarnya pengaruh rumah tangga, tetapi karena pendidikan moral dalam sistem pendidikan kita pada umumnya belum mendapatkan tempat yang sewajarnya.

\section{B. Upaya keluarga dalam Menghadapi Hambatan dalam Mengimplementasikan Pendidikan Agama Islam dalam Keluarga}

Di dalam keluarga, orang tua berperan sebagai pendidik yang utama bagi anakanaknya. Idealnya orang tua diharapkan dapat membimbing, mendidik, melatih dan mengajar anak dalam masalah-masalah yanga menyangkut pembentukan kepribadian dan kegiatan belajar anak. Pendidikan dalam keluarga adalah upaya pembinaan yang dilakukan orang tua terhadap anak agar dapat tumbuh dan berkembanga sebagaimana mestinya. Seluruh potensi anak dapat berkembang, yaitu jasmani, akal dan rohani. Ketida aspek ini merupakan sasaran pendidikan di dalam keluarga yang harus diperhatikan setiap orang tua.

Dalam konteks fungsi edukatif, maka sebuah keluarga muslim (dalam hal ini orang tua) yang paling utama berfungsi dalam memberikan keyakinan agama, nilai budaya, nilai moral dan keterampilan. Berkaitan dengan pemberian keyakinan agama, sesungguhnya anak memang dilahirkan dalam keadaan fitrah maka orang tuanyalah melalui pendidikan di keluarga yang akan menentukan apakah anak tersebut akan menjadi muslim, nasrani, majusi atau yahudi.

Dari uraian di atas jelaslah bahwa peran orang tua dalam pendidikan anak di keluarga sangatlah besar. Tidak berlebihan apabila dikatakan bahwa orang tua adalah central teacher dalam keluarga. Hal ini disebabkan setiap anak mendapatkan pendidikan pertama kali dan biasanya yang paling membekas dari orang tuanya. Orang tua menjadi pendidik pertama dan utama. Kaedah ini ditetapkan secara qodrati, artinya orang tua tidak dapat berbuat lain, mereka harus menempati posisi itu dalam keadaan bagaiamanapun juga. Karena mereka ditakdirkan menjadi orang tua anak yang dilahirkan. Oleh karena itu, mau tidak mau mereka harus menjadi penanggung jawab pertama dan utama. Kaedah ini diakui oleh semua agama dan semua sistem nilai yang dikenal manusia.

Ada pribahasa yang mengatakan "buah tidak jauh jatuh dari pohonnya", artinya, seorang anak tidak akan jauh berbeda dengan watak, tabiat dan kebiasaan orang tuanya. Karena itu, pendidika keluarga yang diberikan oleh orang tua akan berimbas sangat besar terhadap anaknya. Proses pendidikan yang diberikan oleh orang tua kepada anaknya dapat 
melalui beberapa alat pendidikan (non fisik), yaitu, keteladanan, pembiasaan, hukuman dan ganjaran, dan pengawasan. Alat pendidikan non fisik ini dapat difungsikan oleh orang tua di rumah (dalam keluarga) untuk mempengaruhi anak agar melaksanakan nilai-nilai kebaikan dan membina perkembangan potensi dirinya.

Bila alat pendidikan non fisik ini dimanfaatkan secara maksimal oleh orang tua ke arah yang positif maka akan berimbas positif pula terhadap perkembangan anak. Sebaliknya jika alat pendidikan non fisik ini disalahgunakan oleh orang tua, maka akan berdampak negatif terhadap diri anak. Contohnya bila orang tua memberi keteladanan dengan sikap dan perbuatan yang baik, maka anak akan cenderung untuk mengikuti sikap dan perbuatan baik tersebut. Begitu juga sebaliknya.

Adapun upaya keluarga dalam menghadapi kendala implementasi pendidikana agama Islam yaitu: a) orang tua selalu memberikan contoh atau tauladan kepada anak-anaknya, misalnya dalam mengimplementasikan ketaatan kepada Tuhan, orang tua selalu mengajak anak-anaknya sholat lima waktu tepat pada waaktunya; b) mengontrol semua kegiatan anak; c) berkomunikasi $70 \%$ rata-rata keluarga (orang tua) dalam mengimplementasikan pendidikan agama Islam pada anak dengan memasukkan anaknya ke sekolah-sekolah yang berbasis ilmu keagamaan lebih banyak dibanding materi umum. Dengan harapan anak anak mampu mengamalkan nilai-nilai agama dalam kehidupan sehari hari. 30\% rata-rata keluarga dalam mengimplementasaikan pendidikan hanya dilakukan di sekolah atau madrasah saja tanpa ada pemberian uswah/qudwah pada anak, kurangnya komunikasi dan lain sebagainya. Hal ini dikarenakan: 1) orang tua sibuk bekerja; 2) polah asuh anak banyak diserahkan kepada orang lain; 3) anak yang mengalami broken home; dan 4) tidak ada perhatian dalam pendidikan agama Islam di keluarga.

\section{Implikasi Implementasi Pendidikan Agama Islam dalam Keluarga terhadap} Perkembangan Kepribadian Anak.

Kebijakan wajib belajar pendidikan dasar 9 tahun di Indonesia selain merupakan amanat yang tersirat dalam batang tubuh pembukaaan UUD 45 juga tidak lain sebagai upaya untuk memperhatikan dan menciptakan karakter dan perkembangan jiwa anak menjadi berkualitas. Salah satu tujuan yang ingin dicapai ialah seperti dalam pembukaan UUD 1945 adalah "mencerdaskan kehidupan bangsa". Selanjutnya ketentuan tersebut ditegasksn lagi pada pasal 31 ayat (1) yang menyebutkan bahwa tiap-tiap negara berhak dapat pengajaran.

Upaya mencerdaskan kehidupan bangsa yang diamanatkan UUD 1945 seperti yang disebutkan di atas hanya akan tercapai melalui pembangunan nasional, khususnya dalam pendidikan. Karena pendidikan menduduki strata tertinggi dalam pembangunan nasional. 
Peningkatan terhadap kualitas sumberdaya manusia menunjukkan bahwa Indonesia sebagai negara yang berkembang mempunyai komitmen yang kuat untuk mencapai keunggulan dan penguasaan ilmu seperti halnya bangsa-bangsa lainnya. Sumberdaya manusia yang mempunyai penguasaan ilmu dan mempunyai karakter yang baik menjadi salah satu faktor penentu keunggulan tersebut. Peningkatan kualitas sumberdaya manusia akan terasa lebih penting pada masa sekarang mengingat makin besarnya tantangan dan kecenderungan yang akan dihadapi oleh bangsa Indonesia. Tantangan terbesar yaitu pembentukan karakter pada remaja.

Pada hakikatnya pendidikan merupakan upaya pengembangan dan peningkatan kualitas karakater anak yang baik. Pengembangan dan peningkatan kualitas karakter anak didik sekarang ini sangat mendesak untuk segera dilaksanakan karena kemajuan bangsa ini ditentukan oleh baik buruknya karakter remaja. Pendidikan merupakan suatu cara untuk mengembangkan ketrampilan, kebiasaan dan sikap-sikap yang diharapkan dapat membuat seseorang menjadi warga negara yang baik dan memiki moral yang baik. Pada umumnya pendidikan itu merupakan suatu hal yang wajib dilakukan oleh setiap insan. Bahkan orang lama mengatakan bahwasanya tuntutlah ilmu walaupun ke negeri Cina. Pendidikan adalah usaha sadar dan terencana untuk mewujudkan suasana belajar dan proses pembelajaran agar peserta didik secara aktif mengembangkan potensi dirinya untuk memiliki kekuatan spiritual keagamaan, pengendalian diri, kepribadian, kecerdasan, akhlak mulia, serta keterampilan yang diperlukan dirinya dan masyarakat.Pendidikan biasanya berawal saat seorang bayi itu dilahirkan dan berlangsung seumur hidup. Pendidikan bisa saja berawal dari sebelum bayi lahir seperti yang dilakukan oleh banyak orang dengan memainkan musik dan membaca dan mengaji kepada bayi dalam kandungan dengan harapan ia bisa mengajar bayi mereka sebelum kelahiran.

Bagi sebagian orang, pengalaman kehidupan sehari-hari lebih berarti daripada pendidikan formal, seperti kata mark twain "saya tidak pernah membiarkan sekolah mengganggu pendidikan saya". Anggota keluarga mempunyai peran pengajaran yang amat mendalam, sering kali lebih mendalam dari yang disadari mereka, walaupun pengajaran anggota keluarga berjalan secara tidak resmi. Pendidikan yang paling penting adalah pendidikan norma dan moral agama khususnya agama Islam. Pendidikan agama Islam sangat berpengaruh terhadap kepribadian anak untuk menjadi seorang remaja yang sempurna.

Pendidikan agama yaitu meliputi beberapa hal dan ketentuan yang harus diketahui oleh seoarang anak untuk mendampingi hidupnya. Pendidikan agama Islam harus diajarkan kepada anak pada usia dini, agar tertanam kepada anak kepribadian yang baik. Hal utama dalam pendidikan agama yaitu ajaran tentang shalat, sunnah-sunnah rasul, dan Akhlakul 
karimah. Implikasi implementasi pendidikan agama Islam pada keluarga dalam pembentukan karakter anak dapat dilihat dalam kehidupan sehari-hari, baik di rumah maupun di Sekolah. Anak mampu menjalankan sholat lima waktu tanpa harus diperintah, sopan santun dalam bertindak dan bertutur kata, selalu jujur, dan selalu menolong teman.

\section{KESIMPULAN}

Berdasarkan hasil penelitian, maka dapat ditarik kesimpulan sebagai berikut:

1. Implementasi Pendidikan Agama Islam pada keluarga dalam mengembangkan karakter kepribadian anak di MI Al-Wasliyah Sumber Kabupaten Cirebon berdasarkan hasil analisis data angket menunjukkan respon yang baik. Jumlah prosentase pencapaian skor respon siswa adalah sebesar $80 \%$. Skor tersebut tergolong pada kategori kuat yang berada di antara $61 \%$ $80 \%$.

2. Upaya keluarga dalam menghadapi kendala implementasi pendidikana agama Islam yaitu: a) orang tua selalu memberikan contoh atau tauladan kepada anak-anaknya, misalnya dalam mengimplementasikan ketaatan kepada Tuhan, orang tua selalu mengajak anak-anaknya sholat lima waktu tepat pada waaktunya; b) mengontrol semua kegiatan anak; c) berkomunikasi dengan anak.

3. Implikasi implementasi pendidikan agama Islam pada keluarga dalam pembentukan karakter anak dapat dilihat dalam kehidupan sehari-hari, baik di rumah maupun di Sekolah. Anak mampu menjalankan sholat lima waktu tanpa harus diperintah, sopan santun dalam bertindak dan bertutur kata, selalu jujur, dan selalu menolong teman.

\section{DAFTAR PUSTAKA}

Al-Abrasy, A. (1993). Dasar-dasar Pokok Pendidikan Islam. Jakarta: Bulan Bintang

Alwasilah, A. C.(2008). Pokoknya Kualitatif Dasar-dasar Merancang dan Melakukan Penelitian Kualitatif. Bandung: Pustaka Jaya.

Daradjat, Z. (1991). Ilmu Pendidikan Islam, Jakarta: PT. Bumi Aksara

Daradjat, Z. (1995). Pendidikan Islam dalam Keluarga dan Sekolah. Bandung: CV Ruhama.

Daradjat, Z., dkk. (2006). Ilmu Pendidikan Islam: Jakarta: Bumi Aksara dan Direktorat Jenderal Pembinaan Kelembagaan Agama Islam Departemen Agama.

Hurlock, E., B. (2000). Psikologi Perkembangan. Jakarta: Erlangga

Nasution, H. (1995). Islam Rasional. Jakarta : Mizan.

NoerAly, H. (1999). Ilmu Pendidikan Islam. Jakarta: Logos Wacana Ilmu

Undang-Undang No. 20 Tahun 2003 Tentang Sistem Pendidikan Nasional 